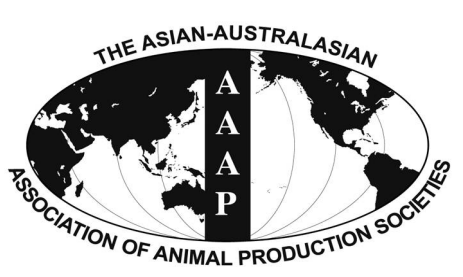

Open Access

Asian Australas. J. Anim. Sci.

Vol. 28, No. 12 : 1669-1679 December 2015

http://dx.doi.org/10.5713/ajas.15.0053

www.ajas.info

pISSN 1011-2367 elSSN 1976-5517

\title{
Potential of Using Maize Cobs in Pig Diets - A Review
}

\author{
A. T. Kanengoni ${ }^{1,2, *}$, M. Chimonyo ${ }^{3}$, B. K. Ndimba $^{4}$, and K. Dzama ${ }^{2}$ \\ ${ }^{1}$ Agricultural Research Council-Animal Production Institute, Pretoria 0062, South Africa
}

\begin{abstract}
The quest to broaden the narrow range of feed ingredients available to pig producers has prompted research on the use of low cost, unconventional feedstuffs, which are typically fibrous and abundant. Maize cobs, a by-product of a major cereal grown worldwide, have potential to be used as a pig feed ingredient. Presently, maize cobs are either dumped or burnt for fuel. The major challenge in using maize cobs in pig diets is their lignocellulosic nature ( $45 \%$ to $55 \%$ cellulose, $25 \%$ to $35 \%$ hemicellulose, and $20 \%$ to $30 \%$ lignin $)$ which is resistant to pigs' digestive enzymes. The high fiber in maize cobs $(930 \mathrm{~g}$ neutral detergent fiber $/ \mathrm{kg}$ dry matter $[\mathrm{DM}] ; 573 \mathrm{~g}$ acid detergent fiber $/ \mathrm{kg} \mathrm{DM}$ ) increases rate of passage and sequestration of nutrients in the fiber reducing their digestion. However, grinding, heating and fermentation can modify the structure of the fibrous components in the maize cobs and improve their utilization. Pigs can also extract up to $25 \%$ of energy maintenance requirements from fermentation products. In addition, dietary fiber improves pig intestinal health by promoting the growth of lactic acid bacteria, which suppress proliferation of pathogenic bacteria in the intestines. This paper reviews maize cob composition and the effect on digestibility of nutrients, intestinal microflora and growth performance and proposes the use of ensiling using exogenous enzymes to enhance utilization in diets of pigs. (Key Words: Ensiling, Exogenous Enzymes, Lignocellulose, Dietary Fiber, Maize Cobs)
\end{abstract}

\section{INTRODUCTION}

Pig producers are faced with a narrow range of ingredients that can be used in formulating pig diets. This has prompted research on the use of low cost, unconventional feedstuffs, which are typically fibrous and abundant, to broaden the feed resource base. Maize (Zea mays L.), a major cereal grown worldwide, generates cobs which can be used as pig feed ingredients (Frank et al., 1983; Kanengoni et al., 2004; Ndubuisi et al., 2008). There are efforts to use maize cobs as an animal feed because of

\footnotetext{
* Corresponding Author: A. T. Kanengoni. Tel: +27-126729355, Fax:+27-126651603, E-mail: Arnoldk@arc.agric.za

2 Department of Animal Sciences, Stellenbosch University, Stellenbosch 7602, South Africa.

${ }^{3}$ Discipline of Animal and Poultry Sciences, University of KwaZulu-Natal, Pietermaritzburg 3209, South Africa.

4 Agricultural Research Council, Proteomics Research and Services Unit, Infruitech-Nietvoorbij Institute, Department of Biotechnology, University of the Western Cape, Cape Town 7535, South Africa.

Submitted Jan. 19, 2015; Revised Mar. 31, 2015; Accepted Jun. 2, 2015
}

the high competing demands with humans for the grain. Estimates of 180 to $200 \mathrm{~kg}$ of maize cobs produced per ton of grains (Božović et al., 2004) translate to significant quantities of maize cobs being potentially available as feed resources. Maize is a staple grain in sub-Saharan Africa, and South Africa produced approximately 2.4 million tons of maize cobs during the 2009 through 2010 season while the other major maize producers in sub-Saharan Africa; Nigeria, Tanzania and Malawi produced approximately 1.5, 0.9 , and 0.7 million tons, respectively (FAO, 2012).

Although maize cob usage is rarely accounted for, there have been efforts to evaluate possible applications in Kenya (Nangole et al., 1983), Ghana (Tuah and Orskov, 1989), Tanzania (Urio and Katagile, 1987), Zimbabwe (Chimonyo et al., 2001; Mashatise et al., 2005) and Nigeria (Opeolu et al., 2009; Raheem and Adesanya, 2011). There are, however, currently no maize cob harvesting technologies and storage facilities at the farm level. Currently the cob is used in its intact form after removal of grain or ground into smaller particles. Farmers, therefore, burn the maize cobs for heating and cooking, plough them back in the fields or throw them away, not only in sub-Saharan Africa (Urio and 
Katagile, 1987; Tuah and Orskov, 1989), but also in Asia and Eastern Europe (Latif and Rajoka, 2001; Božović et al., 2004; Zhang et al., 2010). This review evaluates the physico-chemical composition and utilization of maize cobs as ingredients in pig diets. Approaches to increase utilization of maize cobs through ensiling using exogenous enzymes, are also explored.

\section{PHYSICO-CHEMICAL PROPERTIES OF MAIZE COBS}

Maize cobs fall under the lignocellulose biomass classification; characterized by a close intertwining of cellulose $(45 \%$ to $55 \%)$, hemicellulose ( $25 \%$ to $35 \%)$, and lignin (20\% to 30\%) (Deutschmann and Dekker, 2012; Menon and Rao, 2012). A prerequisite to increasing maize cobs' incorporation into pig diets is a clear understanding of their physico-chemical properties which have a direct bearing on gut fill, fermentation rate and overall digestion of diets. The physico-chemical properties of interest are chemical composition, bulk density, viscosity, water solubility, and water holding capacity (WHC).

\section{Nutrient and chemical composition of maize cobs}

The dry matter (DM), crude protein (CP), ash, neutral detergent fiber (NDF), acid detergent fiber (ADF), and acid detergent lignin of maize cobs are shown in Table 1. The mean CP (30.2 g/kg DM), ash (45.3 g/kg DM), and ether extract $(7.5 \mathrm{~g} / \mathrm{kg} \mathrm{DM})$ of maize cobs (Table 1) are quite low compared to a conventional fiber source such as wheat bran (CP $175 \mathrm{~g} / \mathrm{kg} \mathrm{DM}$, ash $51.2 \mathrm{~g} / \mathrm{kg} \mathrm{DM}$, ether extract 28.3 $\mathrm{g} / \mathrm{kg} \mathrm{DM}$ ) (Huang et al., 2015). The mean fiber components (NDF $816.4 \mathrm{~g} / \mathrm{kg} \mathrm{DM}$ and ADF $520 \mathrm{~g} / \mathrm{kg} \mathrm{DM}$ ) are higher than in wheat bran (NDF $378.8 \mathrm{~g} / \mathrm{kg}$ DM and ADF 111.3 $\mathrm{g} / \mathrm{kg} \mathrm{DM}$ ) (Huang et al., 2015). A digestible energy value of $11 \mathrm{MJ} / \mathrm{kg}$ DM (Viljoen, 1993) and metabolizable energy value of $7 \mathrm{MJ} / \mathrm{kg} \mathrm{DM}$ (Bredon et al., 1987) have been reported.

The composition of maize cobs is affected by stage of maturity, cultivar, climate, soils and production methods (Szyszkowska et al., 2007). Mature cobs have higher NDF, ADF, DM and lower CP and starch than less mature cobs. Szyszkowska et al. (2007) reported that DM content in cobs was positively correlated with the content of starch, and negatively with the content of NDF and ADF fractions. The cultivars tested in the afore-mentioned study did not differ in ADF, NDF, and starch content in cobs. The mineral composition depended on the cultivar, effective temperature sum and the farm type. Maize cobs separate into nutritionally distinct, different sized particles comprising of a hard or woody fraction and a soft fraction consisting of glumes, core, grain clippings and fine dust when ground. Božović et al. (2004) reported that 1-mm-sized maize cobs had higher CP and ether extract and lower cellulose, hemicellulose, ADF and NDF than 3 and $2 \mathrm{~mm}$ particle sized maize cobs. This may have negative implications on mixing of diets as they will not be homogenous allowing for selection by the pigs.

Cellulose is a polysaccharide of alternating linear glucose units linked together by $\beta-(1 \rightarrow 4)$-glycosidic bonds and serves as the main structural component of the cob's cell walls. It is embedded in a matrix of lignin and hemicelluloses, which are branched hetero-polymers of pentoses (xylose, arabinose) and hexoses (glucose, mannose, galactose), sometimes substituted with uronic acids (or their O-methyluronic derivatives), acetyl groups and phenolic compounds in various proportions (Deutschmann and Dekker, 2012; Menon and Rao, 2012). The holo-cellulose (the sum of cellulose and hemicellulose) proportion, ranges from $73 \%$ to $87 \%$ of the total mass (Donnelly et al., 1973 ; Božović et al., 2004; Kumar et al., 2010a,b). The holocellulose consists of $\alpha$ - and $\beta$-cellulose (composed of

Table 1. Nutritional composition of maize cobs

\begin{tabular}{|c|c|c|c|c|c|}
\hline Nutrient ( $\mathrm{g} / \mathrm{kg}$ dry matter) & A & $\mathrm{B}$ & $\mathrm{C}$ & $\mathrm{D}$ & E \\
\hline Dry matter & 908.3 & 885.2 & 900 & - & - \\
\hline Crude protein & 38.9 & 32.6 & 25 & 17.2 & 37.5 \\
\hline Ether extract & 5.7 & - & 6 & 12.3 & 6 \\
\hline Ash & 76.7 & 72.6 & 26 & 13.3 & 38 \\
\hline Crude fiber & 286.9 & - & 324 & 456.8 & 387 \\
\hline Nitrogen free extract & - & - & 529 & 500.4 & 533 \\
\hline Neutral detergent fiber & 706.3 & 929.8 & - & - & 813 \\
\hline Acid detergent lignin & 168.8 & - & - & 116.7 & 44 \\
\hline Acid detergent fiber & 515.8 & 573.2 & - & 570.1 & 421 \\
\hline Cellulose & 347.0 & - & - & 453.4 & 358 \\
\hline Hemicellulose & 190.5 & 179.6 & - & 135.4 & 392 \\
\hline References & Akinfemi (2010) & $\begin{array}{l}\text { Kanengoni et al. } \\
\text { (2004), } \\
\text { Chimonyo et al. } \\
(2001)\end{array}$ & Bredon et al. (1987) & Nangole et al. (1983) & $\begin{array}{c}\text { Stanogias and Pearce } \\
\text { (1985a) }\end{array}$ \\
\hline
\end{tabular}


degraded cellulose) and $\gamma$-cellulose (consisting mainly of hemicelluloses) in proportions of 5.2:2.8:3.0 (Kumar et al., $2010 \mathrm{~b}$ ). In addition to providing structural support, hemicelluloses in certain situations act as seed storage carbohydrates (Scheller and Ulvskov, 2010). Half of maize cob hemicelluloses are xylans (Ebringerová and Heinze, 2000; Vázquez et al., 2006). Xylan is one of the hemicelluloses that has been studied extensively, owing to its diverse applications (Ebringerová and Heinze, 2000; Vázquez et al., 2006). Cellulose and xylans impute waterholding properties, which can result in considerable bulking of digesta (Ndou et al., 2013).

\section{Water solubility and bulk density}

It is unclear how hemicelluloses crosslink with cellulose and lignin, and affect cellulose crystallinity and biomass degradation ( $\mathrm{Xu}$ et al., 2012). These linkages, however, determine the water solubility and bulk density properties associated with maize cobs. Water solubility of maize cobs ranged from $4 \%$ to $11 \%$ and water absorptive capacity ranged from 1.08 to $5.80 \mathrm{~g} / \mathrm{g}$ depending on the size of particles (Božović et al., 2004; Van Nevel et al., 2006). Božović et al. (2004) reported that maize cobs were twice more soluble in sodium hydroxide than in water.

Pathak et al. (1986) compared the bulk density, equilibrium moisture content (EMC) at $80 \%$ relative humidity and gross energy of maize cobs with other crop residues such as Arhar stalks, cotton sticks, maize stalks and rice straw. The EMC describes the moisture state of a hygroscopic material as it equilibrates on a moisture basis with its environment and has implications on shelf life (Igathinathane et al., 2005). Maize cobs had a bulk density of $100 \mathrm{~kg} / \mathrm{m}^{3}$ which ranked as medium compared with Arhar stalks $\left(180 \mathrm{~kg} / \mathrm{m}^{3}\right)$ and wheat straw $\left(60 \mathrm{~kg} / \mathrm{m}^{3}\right)$. Low bulk density residues present handling and storage problems, including poor flow properties. Pathak et al. (1986) reported an EMC of $28 \%$ for maize cobs. This compares favorably with the EMC ranges reported by Igathinathane et al. (2005) of $3.9 \%$ to $56.4 \%$, for maize leaf, $3.1 \%$ to $41.1 \%$ for stalk skin and $2.7 \%$ to $71.5 \%$ for stalk pith. The relatively high EMC values for maize cob explain the greater propensity for the onset of mold growth and may determine minimal storage requirements. Molds increase the risk of mycotoxicosis.

\section{Viscosity}

An increase in solubility of dietary fiber raises luminal viscosity and increases the water-binding capacity of digesta in the small intestine (Canibe and Bach Knudsen, 2002). Montagne et al. (2003) reported that the ability of a fiber substrate to increase viscosity of the intestinal digesta plays a very important role in its effect on the morphological characteristics of the epithelium in the intestinal tract. Van Nevel et al. (2006) reported a lower viscosity of maize cobs $(1.01 \mathrm{mPa} \cdot \mathrm{s})$ compared to sugar beet pulp $(1.67 \mathrm{mPa} \cdot \mathrm{s})$, wheat bran $(1.13 \mathrm{mPa} \cdot \mathrm{s})$ and chicory roots $(1.51 \mathrm{mPa} \cdot \mathrm{s})$. Feeding the different fiber substrates had no effect on viscosity of contents sampled in the jejunum, cecum and colon of weaner piglets.

\section{EFFECTS OF MAIZE COB SUPPLEMENTATION ON GROWTH AND DIGESTIVE PHYSIOLOGY}

The contribution of maize cobs when supplemented in pig diets is complex. The value should not be measured only by the nutrients they contribute, but should encompass their effects on feed intake, the digestibility of other nutrients, intestinal digestive physiology and growth performance. A better understanding of these effects will assist in formulating more accurate and appropriate diets for pigs.

\section{Effects of maize cob inclusion on feed intake and nutrient digestibility}

It would be advantageous to be able to predict feed intake when feeding bulky feeds because they reduce nutrient density and digestibility. This could provide guidance as to the correct concentration of nutrients in diets to ensure adequate intake. Ndou et al. (2013) reported that feed intake was similar in diets containing maize cobs at 80 , 160 , and $240 \mathrm{~g} / \mathrm{kg}$ levels which was attributed to the low WHC of maize cobs. WHC, NDF, and ADF contents of bulky feeds provide relationships with scaled feed intake that can be used to predict gut capacity in weaner pigs even though threshold values for each were different.

Increases in maize cob level in the diet reduced the digestibility of DM, NDF, ADF, hemicellulose, nitrogen, and energy (Table 2). This was attributed to increased rate of passage and sequestration of nutrients in the fiber preventing their digestion (Stanogias and Pearce, 1985a). Fevrier et al. (1992) also reported a decrease in nutrient digestibility as a result of an increase in rate of passage of digesta in pigs fed diets high in inclusion levels of wheat bran. The reduction was, however, less in certain breeds like the Mukota, an indigenous pig from Southern Africa, and in older pigs (Table 2). In the Mukota pigs, digestibility of NDF decreased by about $37 \%$ while in the Large White $\times$ Landrace crosses $(\mathrm{LW} \times \mathrm{LR})$ it decreased by about $46 \%$ when the inclusion level of maize cobs in the diet was increased from 0 to $300 \mathrm{~g} / \mathrm{kg}$ (Kanengoni et al., 2002). Similarly, ADF digestibility reduced by $43 \%$ and $72 \%$ for the Mukota and $\mathrm{LW} \times \mathrm{LR}$ crosses, respectively, as the maize cobs was increased from 0 to $300 \mathrm{~g} / \mathrm{kg}$ in the diet. Explanations for the differences in reduction of digestibility 
Table 2. Digestibility coefficients of dry matter, neutral-detergent fiber, cellulose, hemicellulose, and nitrogen by pigs fed diets containing maize cobs (MC)

\begin{tabular}{|c|c|c|c|c|c|c|c|c|}
\hline \multirow{2}{*}{$\begin{array}{l}\text { Breed } \\
\text { and weight }\end{array}$} & \multirow{2}{*}{$\begin{array}{l}\text { MC level } \\
(\mathrm{g} / \mathrm{kg})\end{array}$} & \multirow{2}{*}{$\begin{array}{l}\text { NDF level } \\
(\mathrm{g} / \mathrm{kg})\end{array}$} & \multicolumn{5}{|c|}{ Nutrients } & \multirow{2}{*}{ References } \\
\hline & & & $\mathrm{DM}$ & $\mathrm{NDF}$ & $\mathrm{ADF}$ & Hemi & $\mathrm{N}$ & \\
\hline \multirow[t]{5}{*}{ LW (45 kg) } & & 75 & 0.87 & 0.23 & 0.27 & 0.32 & 0.92 & Stanogias and Pearce (1985a) \\
\hline & & 150 & 0.81 & 0.10 & 0.18 & 0.02 & 0.89 & \\
\hline & & 225 & 0.76 & 0.21 & 0.24 & 0.20 & 0.88 & \\
\hline & & 300 & 0.69 & 0.18 & 0.20 & 0.20 & 0.84 & \\
\hline & SEM & & 0.008 & 0.031 & 0.036 & 0.032 & 0.007 & \\
\hline \multirow[t]{5}{*}{$\mathrm{LW} \times \mathrm{LR}(75 \mathrm{~kg})$} & 0 & 276.4 & 0.87 & 0.87 & 0.68 & 0.91 & 0.87 & Kanengoni et al. (2002) \\
\hline & 100 & 360.3 & 0.74 & 0.68 & 0.54 & 0.72 & 0.84 & \\
\hline & 200 & 402.9 & 0.75 & 0.59 & 0.51 & 0.61 & 0.83 & \\
\hline & 300 & 523.5 & 0.66 & 0.47 & 0.19 & 0.59 & 0.84 & \\
\hline & SEM & & 0.014 & 0.027 & 0.034 & 0.034 & 0.012 & \\
\hline \multirow[t]{5}{*}{ Mukota $(33 \mathrm{~kg})$} & 0 & 276.4 & 0.86 & 0.86 & 0.69 & 0.90 & 0.86 & \\
\hline & 100 & 360.3 & 0.72 & 0.64 & 0.44 & 0.74 & 0.80 & \\
\hline & 200 & 402.9 & 0.72 & 0.49 & 0.43 & 0.58 & 0.80 & \\
\hline & 300 & 523.5 & 0.65 & 0.54 & 0.39 & 0.65 & 0.79 & \\
\hline & SEM & & 0.014 & 0.027 & 0.034 & 0.034 & 0.012 & \\
\hline \multirow[t]{5}{*}{$\mathrm{LW} \times \mathrm{LR}(42 \mathrm{~kg})$} & 0 & - & 0.86 & - & - & - & 0.86 & Ndubuisi et al. (2008) \\
\hline & 50 & - & 0.82 & - & - & - & 0.84 & \\
\hline & 100 & - & 0.79 & - & - & - & 0.76 & \\
\hline & 150 & - & 0.69 & - & - & - & 0.70 & \\
\hline & SEM & & 0.013 & & & & 0.011 & \\
\hline
\end{tabular}

NDF, neutral-detergent fiber; DM, dry matter; ADF, acid-detergent fiber; Hemi, hemicellulose; N, nitrogen; LW, large white; SEM, standard error of mean; LW $\times$ LR, Large White $\times$ Landrace crosses.

of nutrients were that gut capacity and intestinal microbial Effect of maize cob inclusion on growth performance populations were likely to differ between breeds.

There is a general reduction in average daily gain with increase in maize cob inclusion level (Table 3). However,

Table 3. Growth performance of pigs fed diets containing different levels of maize cobs (MC)

\begin{tabular}{|c|c|c|c|c|c|c|c|}
\hline \multirow{2}{*}{ Breed } & \multirow{2}{*}{$\begin{array}{c}\text { MC level } \\
(\mathrm{g} / \mathrm{kg})\end{array}$} & \multirow{2}{*}{$\begin{array}{l}\text { NDF level } \\
(\mathrm{g} / \mathrm{kg})\end{array}$} & \multicolumn{4}{|c|}{ Growth parameters } & \multirow{2}{*}{ References } \\
\hline & & & IW (kg) & $\mathrm{ADG}(\mathrm{kg})$ & ADFI (kg) & G:F & \\
\hline \multirow[t]{4}{*}{ LW } & 0 & 80 & 30.2 & 0.84 & 2.09 & 0.40 & Frank et al. (1983) \\
\hline & 75 & 135 & 30.4 & 0.81 & 2.21 & 0.37 & \\
\hline & 150 & 189 & 30.5 & 0.79 & 2.33 & 0.34 & \\
\hline & SEM & & 0.4 & 0.01 & 0.03 & 0.005 & \\
\hline \multirow[t]{4}{*}{$\mathrm{LW} \times \mathrm{LR}$} & 0 & 276.4 & 25 & 0.66 & 0.11 & 0.25 & Kanengoni et al. (2004) \\
\hline & 100 & 360.3 & & 0.60 & 0.11 & 0.27 & \\
\hline & 200 & 402.9 & & 0.55 & 0.11 & 0.26 & \\
\hline & 300 & 523.5 & & 0.49 & 0.11 & 0.23 & \\
\hline \multirow[t]{4}{*}{ Mukota } & 0 & 276.4 & 14 & 0.36 & 0.12 & 0.18 & \\
\hline & 100 & 360.3 & & 0.32 & 0.10 & 0.22 & \\
\hline & 200 & 402.9 & & 0.25 & 0.11 & 0.18 & \\
\hline & 300 & 523.5 & & 0.29 & 0.11 & 0.16 & \\
\hline \multirow[t]{5}{*}{$\mathrm{LW} \times \mathrm{LR}$} & 0 & - & 19.4 & 0.56 & 1.54 & 0.36 & Ndubuisi et al. (2008) \\
\hline & 50 & - & 19.3 & 0.58 & 1.68 & 0.35 & \\
\hline & 100 & - & 19.2 & 0.54 & 1.5 & 0.36 & \\
\hline & 150 & - & 19.6 & 0.45 & 1.41 & 0.32 & \\
\hline & SEM & & 0.46 & 0.05 & 0.07 & & \\
\hline
\end{tabular}

NDF, neutral detergent fiber; IW, initial weight; ADG, average daily gain, ADFI, average daily feed intake; G:F, gain:feed; LW, Large White; SEM, standard error of mean; $\mathrm{LW} \times \mathrm{LR}$, Large White $\times$ Landrace crosses.

${ }^{1}$ ADFI: average daily feed intake for the study by Kanengoni et al. (2004) was presented as per metabolic body weight $\left(\mathrm{kg} / \mathrm{body} \mathrm{weight}_{\mathrm{kg}}{ }^{0.75}\right)$. 
Frank et al. (1983) reported individual variability in ability to utilize the higher level maize cob diets such that the pigs could be separated into distinct high, medium and low performance groups. The differences in responses to high fiber diets were attributed to genetic and physiological determinants of feed intake (Frank et al., 1983). Similarly, the Mukota pigs demonstrated an ability to utilize maize cob diets better than commercial breeds (Ndindana et al., 2002; Kanengoni et al., 2004). In a growth performance study, the LW $\times$ LR crosses decreased growth rate by $26 \%$ and the Mukota by $19 \%$ as the maize cobs were increased from 0 to $300 \mathrm{~g} / \mathrm{kg}$ in the diet (Kanengoni et al., 2004). No clear explanations for these differences were given.

An understanding of the adaptive mechanisms employed by the pigs which performed better could be used to better exploit fibrous agricultural by-products leading to either better diet formulations, more precise selection criteria identifying pigs with enhanced ability to utilize fiber or both. On the other hand, because sub-Saharan Africa and the Asian sub-continent have significant populations of indigenous breeds raised by smallholder farmers, these results suggest that they can benefit from maize cob based diets (Chimonyo et al., 2005; Nidup and Moran, 2011). For commercial breeding stock, incorporating high fiber diets with maize cobs is a potentially economically viable proposition.

\section{Effect of maize cob inclusion on gut fermentability and metabolism}

The pigs' ability to extract up to $25 \%$ of energy maintenance requirements from fermentation end products has been documented (Yen et al., 1991). This is derived from volatile fatty acids (VFA), which mainly include acetate, propionate and butyrate. The absorption of VFA occurs in the colon and metabolism occurs in the liver and muscle. The VFA influence changes in glycemia, lipidemia, uremia and nitrogen balance (Tungland and Meyer, 2002). Locally, VFA have a trophic epithelial effect as butyrate is used primarily by the colonocytes, and provides a major source of energy for its metabolic activities (Guilloteau et al., 2010). Investigations on the fermentability of maize cobs produced variable results. Stanogias and Pearce (1985c) reported that diets supplemented with maize cobs resulted in similar VFA concentrations to those having lupin hulls, wheat bran and lucerne stems in the proximal colon of pigs. In contrast, Van Nevel et al. (2006) reported that maize cobs were not degraded in incubations with small intestinal contents and only to a small extent in cecal incubations in vitro compared to sugar beet pulp, chicory roots and wheat bran. There was, however, an increase in lactic acid concentration in the cecum and colon when the maize cobs were included in a diet fed in vivo (Van Nevel et al., 2006). They attributed this to high amounts of fiber from maize cobs reaching the hindgut and potentially being available for degradation and fermentation by the flora.

Ziemer et al. (2012) postulated that pigs on high fiber diets are likely to have high serum glucose concentrations resulting from increased availability of sugars from the fermentation of fiber. However, Frank et al. (1983) reported a linear decrease in plasma glucose and an increase in plasma urea concentrations in cross-bred pigs fed diets with incremental levels of $7.5 \%$ and $15 \%$ maize cobs as fiber sources. The glucose decrease was attributed to less starch in the diet because maize cobs were incorporated in the diet at the expense of grain, while the high urea was because of increased ammonia production by intestinal microbes. Blood urea is a principal product of the catabolism of protein and its concentration can act as an indicator of body protein status (Kohn et al., 2005). It appears that serum energy metabolite concentrations will vary depending on the breed of pig and level of maize cobs in the same way their concentrations vary in response to type of fiber as reported by Weber and Kerr (2012). Mashatise et al. (2005) reported no differences in plasma glucose, urea and creatinine levels in Mukota and Mukota $\times$ Large White gilts fed a control and a high fiber diet with $20 \%$ maize cobs. Pond et al. (1981) observed that obese pigs had lower glucose levels than lean or contemporary pigs. Measurements of serum concentrations of metabolites and hormones including cholesterol, non-esterified fatty acids, leptin and insulin in pigs fed maize cob based diets need to be explored further.

\section{Effect of maize cob inclusion on microbial flora}

Gut microbial diversity is largely influenced by diet, and changes in feed composition affect the species of microbes in the gut, and the type and abundance of fermentation products (Apajalahti et al., 2001,2004; Oviedo-Rondón et al., 2006). Pig microflora contains cellulolytic and hemicellulolytic bacterial species that are also found to be highly active in the rumen. These include Fibrobacter succinogenes (intestinalis), Ruminococcus albus, Ruminococcus flavefaciens, Butyrivibrio species, Prevotella ruminicola, and Clostridium herbivorans (Varel and Yen, 1997). Soluble fibers from pectins and gums have high water-holding capacity allowing bacteria to easily penetrate the matrix, start degradation and multiply whereas insoluble fiber cannot be penetrated easily by bacteria (Metzler and Mosenthin, 2008). The populations of bacteria with cellulolytic and hemicellulolytic activities were reported to increase in pigs fed diets containing high levels of fiber from pectins, gums and $\beta$-glucans (Varel and Yen, 1997; Metzler and Mosenthin, 2008). Cellulolytic bacteria did not increase in sows fed a $20 \%$ maize cob diet (Varel and Pond, 1985). Feeding maize cobs increased the number of total bacteria in the stomach and proximal jejunum 
marked by higher numbers of Lactobacilli and to a less extent an increase in Bifidobacteria (Van Nevel et al., 2006).

The metabolic processes of microbes, in turn, impact directly the host's gut health and nutrient availability. Identification and characterization of intestinal microbes can lead to an analysis of their metabolic profiles and possible impact on the host. This could then be manipulated in such a way as to benefit the host. There is need to determine whether maize cob derived heteroxylans and xylo-oligosaccharides have immuno-stimulatory effects and prebiotic characteristics (Ebringerová et al., 1995; Samanta et al., 2012). Urriola and Stein (2012) suggested that the superiority of the Meishan pig to digest insoluble fiber over the Yorkshire could be a result of differences in the microbial populations or types. Further research is needed to determine the influence of breed on intestinal microbial populations.

\section{Effect of maize cob inclusion on intestinal morphology}

High fiber diets elicit hypertrophy of visceral organs, increase gastric and intestinal secretions and induce variable intestinal villous and cryptic changes in pigs depending on the fiber's physico-chemical characteristics, fiber level, feeding duration and breed or age of the pig (Montagne et al., 2003). Stanogias and Pearce (1985b) reported that prolonged intake of maize cob supplemented diets by growing pigs led to a hypertrophy and increased weight of segments of the gastrointestinal tract, similar to lupin hull, wheat bran, and lucerne stems supplemented diets. The responses were especially marked in the large intestine, and there were increases in mass or length, or both. However, level and type of protein, and particle size also similarly affected the morphology of the intestines (Brunsgaard, 1998). Anugwa et al. (1989) and Wenk (2001) pointed out that the hypertrophy of visceral organs in pigs fed high fiber diets increase the energy requirements of pigs due to the extra metabolic demand and nutrient needs for visceral organ development and maintenance.

Highly viscous diets increase proliferation of the villous and crypt cells by sloughing of the superficial layers translating to changes in the villous/crypt ratio (Montagne et al., 2003). A low villous height/crypt depth ratio was reported to translate to low digestive capacity (Montagne et al., 2003). Van Nevel et al. (2006) reported an increase in the villous height/crypt depth ratio when feeding a maize cob supplemented diet and suggested that it was due to an increased villus height. In addition, the numbers of intraepithelial lymphocytes (IEL) were low in the maize cob supplemented diets indicating a lower renewal rate of the small intestinal mucosa (Van Nevel et al., 2006). Large numbers of the IEL in the villous epithelium indicate a faster renewal rate of the epithelium because they are responsible for clearing damaged or infected cells by apoptosis and cytolytic activity (Nishiyama et al., 2002). Jin et al. (1994) on the other hand, reported that a wheat straw high fiber diet resulted in a greater renewal rate of epithelial cells in pigs. This supports the notion that different fiber sources induce different responses in the pig gastrointestinal tract. Understanding of molecular and cellular mechanisms regulating intestinal nutrient absorption could allow the design of rational and innovative approaches to formulate feed and feed additives to ensure the health and well-being of the animal (Shirazi-Beechey et al., 2011).

\section{APPROACHES TO IMPROVING MAIZE COB UTILIZATION BY PIGS}

To exploit maize cobs effectively as a feed resource, ways to improve their utilization in pig diets should be devised. This can be done through improved processing, and expanding the formulation objectives to include functional properties like prebiotic properties and their potential health benefits.

\section{Processing of maize cobs}

One approach to improve utilization of maize cobs by pigs is through the disruption of their cellulose, hemicellulose and lignin matrices using biological, mechanical and chemical means rendering them more degradable. Limited data are available on the effect of mechanical or chemical processing on changes in fiber utilization in pigs (Kerr and Shurson, 2013). De Vries et al. (2012) reported that processing reduces particle size and solubilizes part of the non-starch polysaccharide (NSP) fraction, such that polysaccharides that are recovered in crude fiber (CF), NDF, and ADF fractions will differ before and after processing. This hampers the evaluation of effects of processing technologies on digestion of NSP. The reduction in particle size and increase in solubility of NSP from processing can also influence site of digestion or fermentation with significant nutritional impact given that the efficiency of energy utilization after hindgut fermentation is generally accepted to be lower. Huang et al. (2015) however concluded that digestible energy content of wheat bran was better fermented in the large intestine at higher inclusion levels. They argued that high inclusion levels reduce the risk of calculation errors in determining nutrient and energy digestibility of fibrous ingredients often encountered with low inclusion levels. Fiber from distilled dried grains with solubles in the ethanol production process is modified by grinding, heating and fermentation of the feedstock making it more digestible than fiber from maize cobs (Le Gall et al., 2009; Urriola et al., 2010). Mechanical processing, use of chemicals and exogenous enzymes, and ensiling have been investigated to improve digestibility of maize cobs. 
Mechanical processing: Maize cobs are commonly processed by either simply grinding using a hammer mill or through a complex process involving various steps of premilling (coarse crushing), separation (into hard or woody and soft or chaffy fractions on air separator), pulverization and granulating (of woody fraction) (Božović et al., 2004). A reduction in particle size of an ingredient like maize cobs increases the surface area available for contact with digestive enzymes in the gastrointestinal tract, thereby influencing their degradation and also affecting their physicochemical characteristics such as their hydration properties (de Vries et al., 2012). After reviewing different studies, de Vries et al. (2012) concluded that mechanical modification of feedstuffs using hammer and roller milling increase solubility of the NSP-fraction resulting in increased apparent total tract digestibility of the fiber fraction by up to 6 or 7 percentage units in both pigs and poultry. However a study by de Vries et al. (2014) demonstrated that processing alone did not improve total tract apparent digestibility of solubilized rape seed meal NSP in broilers indicating that the structures could still not be degraded by cecal microbiota.

Use of chemicals: Menon and Rao (2012) reported on the use of acid, alkali or organic acids to disrupt fiber matrices in lignocellulose biomasses. Concentrated and diluted acids break the rigid structure of the lignocellulosic material. Alkali degrades ester and glycosidic side chains resulting in structural alterations of lignin, cellulose swelling and partial decrystallization of cellulose. Strong acids or bases disrupt lignocellulosic bonds in maize cobs and increase the subsequent hydrolysis (Latif and Rajoka, 2001; Zhang et al., 2010). Božović et al. (2004) showed that maize cobs are highly soluble in sodium hydroxide. Treatment of maize cobs with ammonia and sodium hydroxide significantly reduced fiber levels (Tuah and Orskov, 1989). However, concerns on the use of corrosive substances and the dangers associated with handling chemicals limit their use. Instead, there have been growing trends to explore bio-fermentation processes and use of exogenous enzymes.

Use of exogenous enzymes: Addition of exogenous enzymes to animal feeds to improve nutrient digestion has been reviewed in detail (Chesson, 1993; Bedford, 2000; Kerr and Shurson, 2013). Exogenous enzymes are increasingly being used in pig diets to offset anti-nutritional factors including fiber because pigs lack the appropriate digestive enzymes (Omogbenigun et al., 2004; Jones et al., 2010). The large diversity and concentration of chemical characteristics existing among plant-based feed ingredients, as well as interactions among constituents within feed ingredients and diets necessitate the use of exogenous enzymes to improve usage (Barletta, 2010; Kerr and Shurson, 2013). Improvements in nutrient digestibility and pig performance from adding exogenous enzymes to growing pig diets depend on understanding these characteristics in relation to enzyme activity. In a review, de Vries et al. (2012) postulated that processing technologies and cell wall degrading enzymes such as pectinases, might be used to modify cell wall architecture and improve NSP degradability. Mechanical forces open the cell wall structure and reduce particle size, thereby increasing the surface area accessible for enzymes (i.e., both feed enzymes added to the diet and microbial enzymes present in the gastrointestinal tract) (de Vries et al., 2014).

Studies on the use of exogenous enzymes with maize cobs are scarce, so there is need to identify or develop new enzymes that significantly reduce fiber levels in maize cobs. Given that the main constituents of maize cobs are cellulose and xylan (Ebringerová and Heinze, 2000; Vázquez et al., 2006; Kumar et al., 2010b), different xylanases and cellulases should be investigated singly or as cocktails to investigate potential synergistic efficacy. Appeldoorn et al. (2010) reported that complete enzymatic hydrolysis of the soluble hemicellulose obtained from mild acid pre-treated corn fiber to its constituent monosaccharides could not be reached. This suggests that utilization of single enzyme preparations will not digest the recalcitrant portion of fiber in maize cobs. In a subsequent study, Appeldoorn et al. (2013) used a cocktail of hemicellulolytic enzymes, endo(1-4)- $\beta$-xylanase, $\beta$-xylosidase, and $\alpha$-L-arabinofuranosidases for saccharification to remove arabinose and degrade the xylan backbone and further incubated a fraction with apolar oligosaccharides which had not been hydrolyzed with Ultraflo L and AG-II- Hydrolase which contain ferulolyl esterase activity to successfully remove some ferulolyl groups. They then demonstrated for the first time that maize cob hemicelluloses contain a series of feruloylated oligosaccharides containing an acetyl group attached to the same xylose to which the oligomeric side chain was attached to. They proposed that it was critical to find enzymes able to remove the acetyl groups directly located on the same residue as the oligomeric side chains or enzymes able to hydrolyze the oligomeric side chains. This will boost the hydrolysis of corn fiber glucuronoxylan.

Ensiling: Although ensiling is essentially the use of controlled fermentation to preserve a crop or material of high moisture by creating anaerobic conditions (McDonald et al., 1991), it can also reduce the levels of the fiber in the maize cobs (Gatel et al., 1988; Millet et al., 2005; Khan et al., 2006; Rezaei et al., 2009). Silage fermentation is a dynamic process that requires good anaerobiosis and a low $\mathrm{pH}$; conditions which are unfortunately difficult to attain with maize cobs. A low $\mathrm{pH}$ is normally obtained by the rapid metabolism of water soluble carbohydrates to lactic acid by lactic acid bacteria (LAB) (McDonald et al., 1991). Rapid removal of air and a low $\mathrm{pH}$ prevents the growth of 
unwanted aerobic bacteria, yeasts and molds that compete with beneficial bacteria for substrates (Bolsen et al., 1996; Kung et al., 1998). Drier feedstock such as maize cobs have poor compaction and retain air pockets. In addition, as the DM content of the feedstock increases, growth of LAB is curtailed and the rate and extent of fermentation is reduced, because acidification occurs at a slower rate and the amount of total acid produced is less (Ashbell et al., 1991). If air is not removed quickly, high temperatures and prolonged heating are commonly observed. Addition of cell wall degrading enzymes to maize forage at ensiling improved the chemical characteristics of the resultant silages and reduced fiber content (Sheperd and Kung, 1996; Meeske et al., 1999; Colombatto et al., 2004). The use of ensiling with exogenous enzymes with a view of reducing fiber needs to be explored further. Identifying the correct enzymes effective under silage conditions and with a high specificity for maize cob associated fiber components and determining the optimum conditions for ensiling of maize cobs including possible additives and inoculants are critical areas that need addressing.

\section{CONCLUSIONS}

Maize cobs are underutilized as pig feed in sub-Saharan Africa, yet they are available to most farming households. They affect digestibility, digestive physiology and growth performance of pigs. Different approaches to improve utilization of maize cobs include processing of the maize cobs using chemicals, exogenous enzymes and through ensiling. Combinations of processing technologies followed by enzyme treatments need to be explored further as they appear to produce the most positive results. This information can potentially be used to make practical feed formulating decisions. This can lead to timeous development of effective technologies and models that can be used to utilize maize cobs.

\section{CONFLICT OF INTEREST}

We certify that there is no conflict of interest with any financial organization regarding the material discussed in the manuscript.

\section{REFERENCES}

Akinfemi, A. 2010. Nutritive value and in vitro gas production of fungal treated maize cobs. Afr. J. Food Agric. Nutr. Dev. 10: 2943-2955.

Anugwa, F. O. I., V. H. Varel, J. S. Dickson, W. G. Pond, and L. P. Krook. 1989. Effects of dietary fiber and protein concentration on growth, feed efficiency, visceral organ weights and large intestine microbial populations of swine. J. Nutr. 119:879-886.

Apajalahti, J., A. Kettunen, and H. Graham. 2004. Characteristics of the gastrointestinal microbial communities, with special reference to the chicken. Worlds Poult. Sci. J. 60:223-232.

Apajalahti, J. H. A., A. Kettunen, M. R. Bedford, and W. E. Holben. 2001. Percent $\mathrm{G}+\mathrm{C}$ profiling accurately reveals dietrelated differences in the gastrointestinal microbial community of broiler chickens. Appl. Environ. Microbiol. 67:5656-5667.

Appeldoorn, M. M., P. de Waard, M. A. Kabel, H. Gruppen, and H. A. Schols. 2013. Enzyme resistant feruloylated xylooligomer analogues from thermochemically treated corn fiber contain large side chains, ethyl glycosides and novel sites of acetylation. Carbhydr. Res. 381:33-42.

Appeldoorn, M. M., M. A. Kabel, D. Van Eylen, H. Gruppen, and H. A. Schols. 2010. Characterization of oligomeric xylan structures from corn fiber resistant to pretreatment and simultaneous saccharification and fermentation. J. Agric. Food Chem. 58:11294-11301.

Ashbell, G., Z. G. Weinberg, A. Azrieli, Y. Hen, and B. Horev. 1991. A simple system to study the aerobic determination of silages. Can. Agric. Eng. 33:391-393.

Barletta, A. 2010. Introduction: current market and expected developments. In: Enzymes in Farm Animal Nutrition. 2nd ed. (Eds. M. R. Bedford and G. G. Partridge). CAB International. London, UK. pp. 1-11.

Bedford, M. R. 2000. Exogenous enzymes in monogastric nutrition: their current value and future benefits. Anim. Feed Sci. Technol. 86:1-13.

Bolsen, K. K., G. Ashbell, and Z. G. Weinberg. 1996. Silage fermentation and silage additives: review. Asian Australas. J. Anim. Sci. 9:483-493.

Božović, I., M. Radosavljević, S. Žilić, and R. Jovanović. 2004. A genetic base of utilization of maize cob as a valuable naturally renewable raw material. Genetika 36:245-256.

Bredon, R. M., P. G. Stewart, and T. J. Dugmore. 1987. A Manual on the Nutritive Value and Chemical Composition of Commonly Used South African Farm Feeds. Department of Agriculture and Water Supply, Natal Region, South Africa.

Brunsgaard, G. 1998. Effects of cereal type and feed particle size on morphological characteristics, epithelial cell proliferation, and lectin binding patterns in the large intestine of pigs. J. Anim. Sci. 76:2787-2798.

Canibe, N. and K. E. Bach Knudsen. 2002. Degradation and physicochemical changes of barley and pea fiber along the gastrointestinal tract of pigs. J. Sci. Food Agric. 82:27-39.

Chesson, A. 1993. Feed enzymes. Anim. Feed Sci. Technol. 45:6579.

Chimonyo, M., E. Bhebhe, K. Dzama, T. E. Halimani, and A. Kanengoni. 2005. Improving smallholder pig production for food security and livelihood of the poor in Southern Africa. Afr. Crop Sci. Conf. Proc. 7:569-573.

Chimonyo, M., A. T. Kanengoni, and K. Dzama. 2001. Influence of maize cob inclusion level in pig diets on growth performance and carcass traits of Mukota $\times$ Large White $F_{1}$ crossbred male pigs. Asian Australas. J. Anim. Sci. 14:17241727.

Colombatto, D., F. L. Mould, M. K. Bhat, R. H. Phipps, and E. Owen. 2004. In vitro evaluation of fibrolytic enzymes as additives for maize (Zea mays L.) silage: II. Effects on rate of acidification, fibre degradation during ensiling and rumen fermentation. Anim. Feed Sci. Technol. 111:129-143. 
Deutschmann, R. and R. F. H. Dekker. 2012. From plant biomass to bio-based chemicals: latest developments in xylan research. Biotechnol. Adv. 30:1627-1640.

De Vries, S., A. M. Pustjens, M. A. Kabel, R. P. Kwakkel, and W. J. J. Gerrits. 2014. Effects of processing technologies and pectolytic enzymes on degradability of nonstarch polysaccharides from rapeseed meal in broilers. Poult. Sci. 93:589-598.

De Vries, S., A. M. Pustjens, H. A. Schols, W. H. Hendriks, and W. J. J. Gerrits. 2012. Improving digestive utilization of fiber-rich feedstuffs in pigs and poultry by processing and enzyme technologies: a review. Anim. Feed Sci. Technol. 178:123-138.

Donnelly, B. J., J. L. Helm, and H. A. Lee. 1973. The carbohydrate composition of corn cob hemicelluloses. Cereal Chem. 50:548552.

Ebringerová, A. and T. Heinze. 2000. Xylan and xylan derivatives: biopolymers with valuable properties, 1 . Naturally occurring xylans structures, isolation procedures and properties. Macromol. Rapid Commun. 21:542-556.

Ebringerová, A., Z. Hromádková, and V. Hríbalová. 1995. Structure and mitogenic activities of corn cob heteroxylans. Int. J. Biol. Macromol. 17:327-331.

FAO. 2012. FAOSTAT Crop production. FAOSTAT, FAO Statistics Division. http://faostat.fao.org/site/567/desktopdefault.aspx\#ancor. Accessed December 28, 2012.

Fevrier, C., D. Bourdon, and A. Aumaitre. 1992. Effects of level of dietary fibre from wheat bran on digestibility of nutrients, digestive enzymes and performance in the European Large White and Chinese Mei Shan pig. J. Anim. Physiol. Anim. Nutr. (Berl). 68:60-72.

Frank, G. R., F. X. Aherne, and A. H. Jensen. 1983. A study of the relationship between performance and dietary component digestibilities by swine fed different levels of dietary fiber. J. Anim. Sci. 57:645-654.

Gatel, F., F. Grosjean, and J. Castaing. 1988. Feeding value of ensiled high-moisture maize grain with cob for growingfinishing pigs. Anim. Feed Sci. Technol. 20:145-153.

Guilloteau, P., L. Martin, V. Eeckhaut, R. Ducatelle, R. Zabielski, and F. Van Immerseel. 2010. From the gut to the peripheral tissues: the multiple effects of butyrate. Nutr. Res. Rev. 23:366-384

Huang, Q., Y. B. Su, D. F. Li, L. Liu, C. F. Huang, Z. P. Zhu, and C. H. Lai. 2015. Effects of inclusion levels of wheat bran and body weight on ileal and fecal digestibility in growing pigs. Asian Australas. J. Anim. Sci. 28:847-854.

Igathinathane, C., A. R. Womac, S. Sokhansanj, and L. O. Pordesimo, 2005. Sorption equilibrium moisture characteristics of selected corn stover components. Trans. ASAE 48:1449-1460.

Jin, L., L. P. Reynolds, D. A. Redmer, J. S. Caton, and J. D. Crenshaw. 1994. Effects of dietary fiber on intestinal growth, cell proliferation, and morphology in growing pigs. J. Anim. Sci. 72:2270-2278

Jones, C. K., J. R. Bergstrom, M. D. Tokach, J. M. DeRouchey, R. D. Goodband, J. L. Nelssen, and S. S. Dritz. 2010. Efficacy of commercial enzymes in diets containing various concentrations and sources of dried distillers grains with solubles for nursery pigs. J. Anim. Sci. 88:2084-2091.

Kanengoni, A. T., K. Dzama, M. Chimonyo, J. Kusina, and S. M.
Maswaure. 2004. Growth performance and carcass traits of Large White, Mukota and Large White $\times$ Mukota $F_{1}$ crosses given graded levels of maize cob meal. Anim. Sci. 78:61-66.

Kanengoni, A. T., K. Dzama, M. Chimonyo, J. Kusina, and S. M. Maswaure. 2002. Influence of level of maize cob meal on nutrient digestibility and nitrogen balance in Large White, Mukota and LW - MF 1 crossbred pigs. Anim. Sci. 74:127-134.

Kerr, B. J. and G. C. Shurson. 2013. Strategies to improve fiber utilization in swine. J. Anim. Sci. Biotechnol. 4:11.

Khan, M. A., Z. Iqbal, M. Sarwar, M. Nisa, M. S. Khan, W. S. Lee, H. J. Lee, and H. S. Kim. 2006. Urea treated corncobs ensiled with or without additives for buffaloes: ruminal characteristics, digestibility and nitrogen metabolism. Asian Australas. J. Anim. Sci. 19:705-712.

Kohn, R. A., M. M. Dinneen, and E. Russek-Cohen. 2005. Using blood urea nitrogen to predict nitrogen excretion and efficiency of nitrogen utilization in cattle, sheep, goats, horses, pigs, and rats. J. Anim. Sci. 83:879-889.

Kumar, S., Y. S. Negi, and J. S. Upadhyaya. 2010a. Studies on characterization of corn cob based nanoparticles. Adv. Mater. Lett. 1:246-253.

Kumar, S., J. S. Upadhyaya, and Y. S. Negi. 2010b. Preparation of nanoparticles from corn cobs by chemical treatment methods. BioResources 5:1292-1300.

Kung, L. Jr., A. C. Sheperd, A. M. Smagala, K. M. Endres, C. A. Bessett, N. K. Ranjit, and J. L. Glancey. 1998. The effect of preservatives based on propionic acid on the fermentation and aerobic stability of corn silage and a total mixed ration. J. Dairy Sci. 81:1322-1330.

Latif, F. and M. I. Rajoka. 2001. Production of ethanol and xylitol from corn cobs by yeasts. Bioresour. Technol. 77:57-63.

Le Gall, M., M. Warpechowski, Y. Jaguelin-Peyraud, and J. Noblet. 2009. Influence of dietary fibre level and pelleting on the digestibility of energy and nutrients in growing pigs and adult sows. Animal 3:352-359.

Mashatise, E., H. Hamudikuwanda, K. Dzama, M. Chimonyo, and A. Kanengoni. 2005. Effects of corn cob-based diets on the levels of nutritionally related blood, metabolites and onset of puberty in Mukota and Landrace $\times$ Mukota gilts. Asian Australas. J. Anim. Sci. 18:1469-1474.

McDonald, P., A. R. Henderson, and S. J. E. Heron. 1991. The Biochemistry of Silage. Chalcombe Publications, Marlow, Buckinghamshire, UK. p. 109.

Meeske, R., H. M. Basson, and C. W. Cruywagen, 1999. The effect of a lactic acid bacterial inoculant with enzymes on the fermentation dynamics, intake and digestibility of Digitaria eriantha silage. Anim. Feed Sci. Technol. 81:237-248.

Menon, V. and M. Rao. 2012. Trends in bioconversion of lignocellulose: biofuels, platform chemicals and biorefinery concept. Prog. Energy Combust. Sci. 38:522-550.

Metzler, B. U. and R. Mosenthin. 2008. A review of interactions between dietary fiber and the gastrointestinal microbiota and their consequences on intestinal phosphorus metabolism in growing pigs. Asian Australas. J. Anim. Sci. 21:603-615.

Millet, S., K. Raes, S. De Smet, and G. P. J. Janssens. 2005. Evaluation of corn cob mix in organic finishing pig nutrition. J. Sci. Food Agric. 85:1543-1549.

Montagne, L., J. R. Pluske, and D. J. Hampson. 2003. A review of interactions between dietary fibre and the intestinal mucosa, 
and their consequences on digestive health in young nonruminant animals. Anim. Feed Sci. Technol. 108:95-117.

Nangole, F. N., H. Kayongo-Male, and A. N. Said. 1983. Chemical composition, digestibility and feeding value of maize cobs. Anim. Feed Sci. Technol. 9:121-130.

Ndindana, W., K. Dzama, P. N. B. Ndiweni, S. M. Maswaure, and M. Chimonyo. 2002. Digestibility of high fibre diets and performance of growing Zimbabwean indigenous Mukota pigs and exotic Large White pigs fed maize based diets with graded levels of maize cobs. Anim. Feed Sci. Technol. 97:199-208.

Ndou, S. P., R. M. Gous, and M. Chimonyo. 2013. Prediction of scaled feed intake in weaner pigs using physico-chemical properties of fibrous feeds. Br. J. Nutr. 110:774-780.

Ndubuisi, E. C., F. C. Iheukwumere, and M. U. Onyekwere. 2008. The effect of varying dietary levels of maize cob meal on the growth and nutrient digestibility of grower pigs. Res. J. Anim. Sci. 2:100-102.

Nidup, K. and C. Moran. 2011. Genetic diversity of domestic pigs as revealed by microsatellites: a mini review. Genomics Quant. Genet. 2:5-18.

Nishiyama, Y., H. Hamada, S. Nonaka, H. Yamamoto, M. Nanno, Y. Katayama, H. Takahashi, and H. Ishikawa. 2002. Homeostatic regulation of intestinal villous epithelia by $\mathrm{B}$ lymphocytes. J. Immunol. 168:2626- 2633.

Omogbenigun, F. O., C. M. Nyachoti, and B. A. Slominski. 2004. Dietary supplementation with multienzyme preparations improves nutrient utilization and growth performance in weaned pigs. J. Anim. Sci. 82:1053-1061.

Opeolu, B. O., O. Bamgbose, T. A. Arowolo, and M. T. Adetunji. 2009. Utilization of maize (Zea mays) cob as an adsorbent for lead (II) removal from aqueous solutions and industrial effluents. Afr. J. Biotechnol. 8:1567-1573.

Oviedo-Rondón, E. O., M. E. Hume, C. Hernández, and S. Clemente-Hernández. 2006. Intestinal microbial ecology of broilers vaccinated and challenged with mixed Eimeria species, and supplemented with essential oil blends. Poult. Sci. 85:854860.

Pathak, B. S., A. K. Jain, and A. Singh. 1986. Characteristics of crop residues. Agric. Wastes 16:27-35.

Pond, W. G., J. T. Yen, R. N. Lindvall, and D. Hill. 1980. Dietary alfalfa meal for genetically obese and lean growing pigs: effect on body weight gain and on carcass and gastrointestinal tract measurements and blood metabolites. J. Anim. Sci. 51:367-373.

Raheem, A. A. and D. A. Adesanya. 2011. A study of thermal conductivity of corn cob ash blended cement mortar. Pac. J. Sci. Technol. 12:106-111.

Rezaei, J., Y. Rouzbehan, and H. Fazaeli. 2009. Nutritive value of fresh and ensiled amaranth (Amaranthus hypochondriacus) treated with different levels of molasses. Anim. Feed Sci. Technol. 151:153-160.

Samanta, A. K., S. Senani, A. P. Kolte, M. Sridhar, K. T. Sampath, N. Jayapal, and A. Devi. 2012. Production and in vitro evaluation of xylooligosaccharides generated from corn cobs. Food Bioprod. Process. 90:466-474.

Scheller, H. V. and P. Ulvskov. 2010. Hemicelluloses. Annu. Rev. Plant Biol. 61:263-289.

Sheperd, A. C. and L. Jr. Kung. 1996. Effects of an enzyme additive on composition of corn silage ensiled at various stages of maturity. J. Dairy Sci. 79:1767-1773.
Shirazi-Beechey, S. P., A. W. Moran, D. Bravo, and M. AlRammahi. 2011. Nonruminant Nutrition Symposium: intestinal glucose sensing and regulation of glucose absorption: implications for swine nutrition. J. Anim. Sci. 89:1854-1862.

Stanogias, G. and G. R. Pearce. 1985a. The digestion of fibre by pigs. 1. The effects of amount and type of fibre on apparent digestibility, nitrogen balance and rate of passage. Br. J. Nutr. 53:513-530.

Stanogias, G. and G. R. Pearce. 1985b. The digestion of fibre by pigs. 2. Volatile fatty acid concentrations in large intestine digesta. Br. J. Nutr. 53:531-536.

Stanogias, G. and G. R. Pearce. 1985c. The digestion of fibre by pigs. 3. Effects of the amount and type of fibre on physical characteristics of segments of the gastrointestinal tract. Br. J. Nutr. 53:537-548.

Szyszkowska, A., J. Sowiński, and H. Wierzbicki. 2007. Changes in the chemical composition of maize cobs depending on the cultivar, effective temperature sum and farm type. Acta Sci. Pol. Agric. 6:13-22.

Tuah, A. and E. Orskov. 1989. The degradation of untreated and treated maize cobs and cocoa pod husks in the rumen. Proc. of the 4th Ann. Workshop held at the Institute of Animal Research, Mankon Station, Bamenda, Cameroun, 20-27 October 1987 entitled, Overcoming constraints to the efficient utilization of agricultural by-products as animal feed. Food and Agriculture Organization of the United Nations. http://www.fao.org/wairdocs/ilri/x5490e/x5490e0t.htm.

Accessed February 21, 2011.

Tungland, B. C. and D. Meyer. 2002. Nondigestible oligo- and polysaccharides (dietary fiber): Their physiology and role in human health and food. Compr. Rev. Food Sci. Food Saf. 1:90109

Urio, N. A. and J. A. Katagile. 1987. Maize stover and cobs as a feed resource for ruminants in Tanzania. In: Proceedings of a workshop held at Ryall's Hotel, Blantyre, Malawi. pp. 37-44.

Urriola, P. E., G. C. Shurson, and H. H. Stein. 2010. Digestibility of dietary fiber in distillers coproducts fed to growing pigs. J. Anim. Sci. 88:2373-2381.

Urriola, P. E. and H. H. Stein. 2012. Comparative digestibility of energy and nutrients in fibrous feed ingredients fed to Meishan and Yorkshire pigs. J. Anim. Sci. 90:802-812.

Van Nevel, C. J., N. A. Dierick, J. A. Decuypere, and S. M. De Smet. 2006. In vitro fermentability and physicochemical properties of fibre substrates and their effect on bacteriological and morphological characteristics of the gastrointestinal tract of newly weaned piglets. Arch. Anim. Nutr. 60:477-500.

Varel, V. H. and J. T. Yen. 1997. Microbial perspective on fiber utilization by swine. J. Anim. Sci. 75:2715-2722.

Varel, V. H. and W. G. Pond. 1985. Enumeration and activity of cellulolytic bacteria from gestating swine fed various levels of dietary fiber. Appl. Environ. Microbiol. 49:858-862.

Vázquez, M. J., J. L. Alonso, H. Domínguez, and J. C. Parajó. 2006. Enhancing the potential of oligosaccharides from corncob autohydrolysis as prebiotic food ingredients. Ind. Crops Prod. 24:152-159.

Viljoen, J. 1993. Feed sources: use and feed tables. In: Pig production in South Africa. Irene Animal Production Institute. Agricultural Research Council, Bulletin 427 (Ed. E.H. Kemm). Agricultural Research Council, Pretoria, pp 53. 
Weber, T. E. and B. J. Kerr. 2012. Metabolic effects of dietary sugar beet pulp or wheat bran in growing female pigs. J. Anim. Sci. 90:523-532.

Wenk, C. 2001. The role of dietary fibre in the digestive physiology of the pig. Anim. Feed Sci. Technol. 90:21-33.

Xu, N., W. Zhang, S. Ren, F. Liu, C. Zhao, H. Liao, Z. Xu, J. Huang, Q. Li, Y. Tu, B. Yu, Y. Wang, J. Jiang, J. Qin, and L. Peng. 2012. Hemicelluloses negatively affect lignocellulose crystallinity for high biomass digestibility under $\mathrm{NaOH}$ and $\mathrm{H}_{2} \mathrm{SO}_{4}$ pretreatments in Miscanthus. Biotechnol. Biofuels 5:58.
Yen, J. T., J. A. Nienaber, D. A. Hill, and W. G. Pond. 1991. Potential contribution of absorbed volatile fatty acids to wholeanimal energy requirement in conscious swine. J. Anim. Sci. 69:2001-2012.

Zhang, M., F. Wang, R. Su, W. Qi, and Z. He. 2010. Ethanol production from high dry matter corncob using fed-batch simultaneous saccharification and fermentation after combined pretreatment. Bioresour. Technol. 101:4959-4964.

Ziemer, C. J., B. J. Kerr, T. E. Weber, S. Arcidiacono, M. Morrison, and A. Ragauskas. 2012. Effects of feeding fiber-fermenting bacteria to pigs on nutrient digestion, fecal output, and plasma energy metabolites. J. Anim. Sci. 90:4020-4027. 